CATALAN REVIEW

Catalan Review

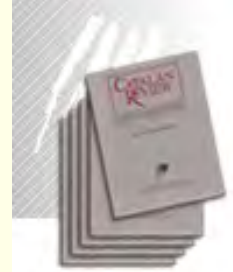

You are accessing the Digital Archive of the Catalan Review Journal.

By accessing and/or using this Digital Archive, you accept and agree to abide by the Terms and Conditions of Use available at http://www.nacs-

catalanstudies.org/catalan review.html

Catalan Review is the premier international scholarly journal devoted to all aspects of Catalan culture. By Catalan culture is understood all manifestations of intellectual and artistic life produced in the Catalan language or in the geographical areas where Catalan is spoken. Catalan Review has been in publication since 1986.
NORTH

AMERICAN

CATALAN

SOCIETY
Esteu accedint a l'Arxiu Digital del Catalan Review

A l' accedir i / o utilitzar aquest Arxiu Digital, vostè accepta i es compromet a complir els termes i condicions d'ús disponibles a http://www.nacs-

catalanstudies.org/catalan review.html

Catalan Review és la primera revista internacional dedicada a tots els aspectes de la cultura catalana. Per la cultura catalana s'entén totes les manifestacions de la vida intel lectual i artística produïda en llengua catalana o en les zones geogràfiques on es parla català. Catalan Review es publica des de 1986.

\title{
The Emergence of L2 Imperfective Morphology in Narrative Retellings and Conversations Llorenç Comajoan
}

Catalan Review, Vol. XIX, (2005), p. 79-108 


\title{
THE EMERGENCE OF L 2 IMPERFECTIVE MORPHOLOGY IN NARRATIVE RETELLINGS AND CONVERSATIONS'
}

\author{
LLORENÇ COMAJOAN
}

\begin{abstract}
This study focuses on the L2 acquisition of Catalan imperfect morphology by three adult learners during a period of seven months. The results provided evidence of the association between the atelic lexical categories and the emergence of imperfect morphology. Data from two types of narratives (retellings and conversations) showed that use of imperfect in the data from conversations was higher than in the retellings. These results are discussed in relation to the aspect hypothesis and the marked status of imperfect morphology.
\end{abstract}

\section{THE ASPECT HYPOTHESIS IN SECOND LANGUAGE ACQUISITION}

Restron

escarch in the acquisition of second language $\left(\mathrm{L}_{2}\right)$ verbal morphology has focused on the acquisition of the perfectiveimperfective distinction and more specifically on the patterns of emergence and development of past morphological forms (e.g., simple past and past progressive in English, pretérito and imperfecto in Spanish, and passé composé and imparfait in French). Most research has been conducted within the so-called aspect hypothesis, which predicts a pattern of emergence and development according to the lexico-aspectual characteristics of verbal predicates (Andersen $\&$ Shirai, 1996; Bardovi-Harlig, 2000; Salaberry \& Ayoun, 2005). ${ }^{2}$

As far as the acquisition of Romance languages by beginning learners, the aspect hypothesis predicts the following two paths of emergence and development of past morphology: (I) Learners first use

1. Acknowledgements: I am thankful to Joaquim Camps, Rafael Salaberry, and two Catalan Review anonymous reviewers for their comments. I am also grateful to the parricipants of this study for their patience. The research in this article has been partly funded by a C-RED 2004 grant from the Government of Catalonia to the Departament of Linguisties of the University of Barcelona.

2. Research in the aspect hypothesis in second language acquisition has been greatly influenced by child acquisition studies (see Weist, 2002 for a general review; and Bel, 200I; Bronckart \& Bourdin, 1993 ; Cortés \& Vila, 199r; and Serra et al., 2000 for the Li acquisition of Spanish and Catalan verbal morphology). 
perfective morphology (e.g., Catalan periphrastic past) in verbal predicates that have an inherent endpoint (i.e., in predicates with achievements and accomplishments, e.g., arribar, "arrive," and cantar una cançó, "sing a song") and later extend perfective marking to the remainder of predicates (i.e., those without an inherent endpoint: activities and states, e.g., cantar, "to sing" and creure, "to believe"). (2) Imperfective morphology (e.g., Catalan imperfect forms) emerges after perfective morphology, it does so in state and activity predicates, and later it extends to predicates with an inherent endpoint (accomplishments and achievements). ${ }^{3}$ In brief, perfective morphology emerges before imperfective morphology, and the two types of morphology develop in opposed paths depending on the lexicoaspectual characteristics of the verbal predicates.

The four aspectual categories mentioned in the aspect hypothesis (state, activity, accomplishment, and achievement) are related to the concepts of temporality and tense-aspect (Binnick, 1991; Comrie, 1976, 1985). In $\mathrm{L}_{2}$ studies, the classification of predicates into aspectual categories that is most widely used is Vendler (1967), which classifies the four categories according to three aspectual features: punctuality, telicity, and dynamicity (Table $\mathrm{I}$ ). ${ }^{4}$

TABLE 1. Verbal aspectual classes

(from Andersen, 1991; Smith, 1997; Vendler, 1967)

Atelic

Telic

\begin{tabular}{lcccc}
\hline & $\begin{array}{c}\text { States } \\
\text { (ST) }\end{array}$ & $\begin{array}{c}\text { Activities } \\
\text { (ACT) }\end{array}$ & $\begin{array}{c}\text { Accomplishments } \\
\text { (ACC) }\end{array}$ & $\begin{array}{c}\text { Achievements } \\
\text { (ACH) }\end{array}$ \\
\hline $\begin{array}{c}\text { creure } \\
\text { "believe" }\end{array}$ & $\begin{array}{c}\text { cantar } \\
\text { "sing" }\end{array}$ & $\begin{array}{c}\text { cantar una cançó } \\
\text { "sing a song" }\end{array}$ & $\begin{array}{c}\text { arribar } \\
\text { "arrive" }\end{array}$ \\
\hline $\begin{array}{l}\text { Punctual } \\
\text { Telic }\end{array}$ & - & - & - & + \\
Dynamic & - & - & + & + \\
\hline
\end{tabular}

3. Research in the aspect hypothesis often refers to the extension and development of morphology from the prototypical classes (perfective morphology in achievement and accomplishment predicates, imperfective morphology from state predicates) to the nonprototypical classes as the spread of morphology.

4. Although there are alternatives to the four-class Vendlerian classification (see Andersen \& Shirai, 1996; Verkuyl, 1993 for a review of other classifications), most acquisitional studies have adopted the four-class typology, because there is a well defined set of operational tests for several languages (e.g., De Miguel, 1999 for Spanish; Dowty, 1979 and Mittwoch, 199r for English; and Pérez Saldanya, 2002 for Catalan). 
Achievement and accomplishment predicates can be grouped under the telic category (with endpoints), whereas state and activity categories are grouped under the atelic category. The categories in Table $\mathrm{I}$ are also referred to as lexical aspect, which contrasts with morphological (or grammatical) aspect. Lexical aspect is lexically encoded; that is, the aspectual characteristics of the predicate are determined by the lexical items in a predicate. For instance, the aspectual differences in the English and Catalan sentences in (I), (2), and (3) are due to a difference in the lexical items of the arguments of the predicate run and córrer in (I) and (2) respectively, and to different lexical items in the verbal predicates in (1)-(2) and (3):

\section{(i) Corre squilòmetres. \\ "He runs 5 kilometers." [Accomplishment] \\ (2) Corre. \\ "He runs." / "He is running." [Activity] \\ (3) Arriba a les to. \\ "He arrives at to o'clock." [Achievement]}

On the other hand, grammatical aspect is encoded overtly by verbal morphology. For instance, (4) and (5) contain the same lexical item (ballar "dance"), but the two sentences are aspectually different due to the use of perfective morphology in (4) and continuousimperfective morphology in (5).
(4) Va ballar abir.
"He danced yesterday." [Activity]
(5) Ballava abir.
"He was dancing yesterday." [Activity]

The tense categories in Catalan are present, past, and future; and the aspect categories are perfective and imperfective (Badia, 1994; Pérez Saldanya, 2002; Wheeler, Yates, \& Dols, 1999). S Similar to Spanish, French, and Italian, the distinction between perfective and imperfective aspect in the past in Catalan is marked morphologically by way of two distinct forms: periphrastic past (PerP) and imperfect (Imp), respectively. ${ }^{6}$

5. This study focuses on perfective-imperfective aspect. For a discussion of progressive aspect in Catalan, see Espunya (I996), Laca (1995), and Pérez-Saldanya (2002). See Blasco (1982) for a structuralist account of tense and aspect in Catalan.

6. The terms to refer to Catalan past perfective and imperfecrive forms have varied depending on the linguistic tradition of the moment. The terminology used in this study is based on Pérez Saldanya (2002). Periphrastic past (PerP) is the term to refer to perfec- 
Whereas the Catalan imperfect inflection is added to a verbal root (e.g., ava, third person singular imperfect morphology in (5)), Catalan perfective forms are periphrastic. For instance, the perfective form in (4) is composed of the grammaticalized form of the auxiliary anar, "to go" (va, inflected for person and number) followed by the verb infinitive (ballar, "dance").7

Perfective aspect in Catalan is more homogeneous than imperfective in the sense that it has one basic meaning (view the event as a whole) (6):

Ahir vaig fer el sopar.

"Yesterday 1 cooked dinner."

In contrast, imperfective aspect in Catalan is muldimensional in the sense that it marks three aspectual meanings: habitual (7), progressive (8), and continuous (9) (Comajoan, 2005a; Pérez Saldanya, 2002):

(7) De petit em quedava a dinar a l'escola. "In my childhood, I stayed at school for lunch."

(8) Quan vaig arribar, parlava per telèfon. "When I arrived, she was talking on the phone."

(9) En Joan era molt simpàtic. "Joan was very nice."

Finally, imperfective forms fulfill a variety of discourse functions, but in narratives their main function is to mark the background (see Pérez Saldanya, 2002). For instance, in the following narrative segment from one of the learners of Catalan who participated in this study, imperfective (Imp) forms mark the background, and perfective (PerP) forms mark the foreground (Comajoan, 2005a, p. 67):

tive forms (e.g., Vaig viure [PerP] a Chicago quatre anys "I lived in Chicago for four years," and imperfect (Imp) is the term to refer to imperfective forms (e.g, Quan vivia [Imp] a Chicago, treballava [Imp] a la universitat, "When I was living in Chicago, I was working at the university"). See Brucart \& Rigau (1997) and Pérez Saldanya (2002) for a discussion of the different terms used in the Catalan linguistic tradition. The terms pretérito and imperfecto are shortened versions of pretérito indefinido (copretérito) and pretèrito imperfecto (see Rojo \& Veiga, 1999 for a discussion of the Spanish terminology).

7. Verbal periphrases with grammaticalized forms of "go" in other Romance languages most commonly mark future temporality (e.g, in Spanish and French). For the diachronical evolution of the Catalan periphrastic past, see Pérez-Saldanya (1996, 1998). Nonperiphrastic synthetic perfective forms exist in Catalan, and they are commonly used in specific Catalan varieties (mostly in the Balearic and Valencian dialects). The nonperiphrastic forms were not taught to the learners who participated in this study. 
(10) Hi havia una noia que tenia molta fam i va veure un camió d'una pastisseria i un empleat de la pastisseria descargava pa. Quan l'empleat va entrar a la pastisseria la noia va robar el $\mathrm{pa}$. "There was [Imp] a girl who was [Imp] very hungry, and she saw [PerP] a bakery truck, and a bakery employee was unloading [Imp] bread. When the employee walked [PerP] into the bakery, the girl stole [PerP] the bread."

In sum, perfective and imperfective verbal forms in Catalan, as in other Romance languages, have a determining role in representing not only time information, but also in structuring the manner in which the information is represented through language.

\section{THE ACQUISITION OF ROMANCE PERFECTIVE-IMPERFECTIVE MORPHOLOGY}

Even though the stage-by-stage development of perfective and imperfective forms according to lexical aspect posited by Andersen (1991) (the aspect hypothesis) has not been fully confirmed, $\mathrm{L}_{2}$ research indicates that the lexico-aspectual characteristics of predicates play a role in the emergence of morphology (Comajoan, 2005b). More specifically, current research is investigating how the lexical characteristics interact with discourse characteristics as well as with classroom instruction, the learners' LI, elicitation methods, and the acquisition of syntactic features (see Montrul \& Salaberry, 2003 and Salaberry \& Ayoun, 2005 for a review). 8

Studies in the acquisition of Romance languages have focused on the contrast between perfective and imperfective morphology, and in general more prominence has been given to the study of perfective forms for reasons related to methodology and learner production.? As argued by Bardovi-Harlig (2005), learners produce fewer imperfective than perfective tokens in production tasks, and the few imperfective tokens produced by learners represent a limited number of lexical items in specific tasks (impersonal narratives do not favor the use of states and background information, which may be an additional factor for the scarcity of imperfect forms in impersonal narratives). In

8. The focus of this study is the acquisition of verbal morphology as a marker of temporality. However, it is acknowledged that learners do mark temporality through linguistic devices other than verbal morphology, such as lexical and pragmatic devices (Bardovi-Harlig, 2000; Dietrich, Klein, \& Noyau, 1995).

9. In Romance linguistics, several studies have focused on imperfectivity by its own (see García Fernández \& Camus, 2003 for Spanish and Bres, 2003 for French). 
addition, fewer $\mathrm{L}_{2}$ studies have focused on the imperfect partly because most $\mathrm{L}_{2}$ studies are based on English, which does not mark imperfectivity with specific morphology.

Overall, previous studies have found that learners produce more tokens of perfective than imperfective morphology and that the acquisition of perfective forms (emergence in specific aspectual predicates and further development to all types of predicates) is faster for perfective than imperfective forms (Ayoun, 2001, 2004, 2005; Camps, 2002, 2005; Salaberry, 2000).

The path of acquisition of imperfective past $\mathrm{L}_{2}$ morphology is summarized as follows by Kihsltedt's (2002, p. 327) statements regarding the acquisition of $\mathrm{L}_{2}$ French imperfect morphology: (a) Imperfective morphology emerges after perfective morphology; (b) imperfective morphology is less frequent in the data than perfective morphology, and (c) initially, imperfective morphology is associated with a few high-frequency state verbs. The studies that have specifically focused on the acquisition of imperfect and states have allowed for the refinement of Kihlstedt's observations. Specifically, results from previous research have provided evidence for the role of type of task (Camps, 2002), the lexical variety of the state category (Camps, 2005), and the order of emergence and spread of imperfect (Camps, 2005; Comajoan, 2005a; Salaberry, 2000, 2005; Kihlstedt, 2002; Giacalone Ramat, 2002).

Regarding task effects, in a study of the acquisition of Spanish by beginner learners, Camps' (2003) results showed that there was high variability in the frequency of stative verbs and that the category of states was not as homogeneous as previously thought. For instance, Camps (2003) found that the most frequently used Spanish state verbs (tener, "have," ser-estar, "be," and gustar, "like") were inflected in the imperfect; whereas the less frequently used statives showed a text effect (they were inflected in the preterite in a task in which learners had to retell specific past events, and they were inflected in the imperfect in a habitual past narrative). The type of task also played an important role in the general use of state verbs (and, thus, higher inflection of imperfect): A personalized narrative elicited more state verbs than an impersonal narrative, and inflection of state verbs in the personalized narrative was more varied than in the impersonal narrative (ser, "be" with imperfect; tener, "have" with preterite; and estar, "be" depended on the type and token counts).

Salaberry (2003) provided further evidence of the role of task type in the acquisition of Spanish preterite and imperfect. In the results from fictional narratives, lexical class did not have a significant effect in the inflection of past morphology, and learners used a default form (the preterite) for all lexical predicates. However, in personal narratives, the 
use of imperfect was significantly lower than the use of preterite in all types of predicates, but only in the advanced group. Surprisingly, beginning learners in the personal narrative used a default form as well, but it was the imperfect. Salaberry explained these results arguing that learners choose a default marker by noticing the most common marker for a specific narrative context. Thus, in personal narratives, learners are supposedly aware that there are more descriptions and background information, which triggers the use of the imperfect.

Kihlstedt (2002) analyzed interview data from four advanced university students of French (Swedish Lr) and found a high degree of variability in the acquisition of passé composé and imparfait by advanced learners. Overall, she found evidence for the spread of passé composé, but not of imparfait; which suggests that learners only used imparfait after they had used passé composé in all types of predicates. Thus, Kihlstedt (2002) posited the following sequence of acquisition of French imperfective forms (p. 343): learners initially used imparfait with frequent stative verbs; at a later stage, they used imparfait in activity predicates already inflected in passé composé, and eventually they used imparfait with a variety of dynamic verbs.

Camps (2005) studied the acquisition of Spanish Lz imperfect by 30 first-year learners at the university level and confirmed the strong association between state verbs and imperfective morphology and their later extension to activity predicates. Imperfect morphology was not only more frequently used in state predicates than in the other predicates but also more appropriately used. Camps (2005) also confirmed Kihlstedt's (2002) claim that learners begin to use imperfect in activity predicates that were earlier inflected in the preterite.

Salaberry (2005) found that learners of L3 Portuguese (with advanced proficiency of $\mathrm{L}_{2}$ Spanish) transferred their knowledge of aspectual marking from Spanish to Portuguese in all categories except states. Thus, whereas the Portuguese native speakers and $\mathrm{L}_{3}$ learners marked achievement, accomplishment, and activity predicates in a similar manner (achievements and accomplishments with perfective forms, activities with imperfective forms); the $\mathrm{L}_{3}$ learners did not mark states in a homogeneous manner. In addition, contrary to the predictions of the aspect hypothesis, imperfective morphology had spread to all types of predicates before perfective morphology.

Finally, Camps (2005), Comajoan (2005a), Giacalone Ramat (2002), and Howard (2004) argued that the acquisition of perfective and imperfective forms and their relationship to lexical categories cannot be separated from their function as markers of discourse information (foreground and background) in narratives.

In sum, previous research has begun to study the acquisition of imperfective morphology by its own, but it has not yet fully explored 
how imperfective morphology develops longitudinally at the beginning stages of acquisition in different types of narrative tasks. The current study focuses on the early stages of acquisition and addresses the following issues: (a) the pattern of emergence in relation to lexical categories, (b) the order of emergence of Catalan periphrastic past and imperfect, and (c) the differences in emergence of morphology in two types of narrative tasks.

\section{STUDY}

\section{Participants, tasks, and procedure}

The participants for this study came from an introductory class of Catalan as a foreign language at a large Midwestern university in the United States. The period of study lasted 7 months (approximately two university semesters). During the first semester, the class met for three 5o-minute periods each week. Two of the periods were dedicated to learning the language and one to introducing culture and literature topics. The language classes followed a communicative approach with emphasis on oral skills and everyday situations. ${ }^{10}$ When data collection started, the subjects had been exposed to 16 language sessions and 8 culture-literature sessions. The only verbal morphology that was explicitly taught during the first semester was present tense. Input in the classroom, however, contained plenty of examples of periphrastic past and imperfect, especially during the culture and literature sessions, which were conducted entirely in the target language. The Catalan class during the first semester was taught by a native speaker of Catalan.

In the second semester, the three learners did not take the Catalan class for university credit, but they continued to study the language on a voluntary basis. The author of this study taught the class during the second semester, when students were introduced to several grammatical structures of Catalan, including periphrastic past and imperfect morphology and use. The methodology and textbook for the second semester were the same as the first semester.

The three participants in this study (Daniel, Barbara, and Robert) were English native speakers who had no previous knowledge of Catalan but who had an intermediate or advanced level of Spanish and French. In addition, Robert and Barbara had some knowledge of another foreign language (Romanian, Italian, Korean, or German)."

10. The teaching materials for the class were Digui Digui by Mas, Melcion, Rosanas, and Vergés (1991).

n. The data for this study come from a larger corpus of data that included six lear- 
The data come from fictional narratives elicited through retellings of a movie clip ("Alone and Hungry", from Modern Times; Chaplin, 1936) and one storybook (The Legend of Saint George; Vinyes \& Rifà, 1986) and from semi-spontaneous personal conversations between the participants and the researcher.

The development of morphology was studied in two stages. Stage I comprised the first three months of acquisition (first semester), and Stage 2 comprised the following four months (second semester). Each participant produced four retellings of Modern Times (at four different times, two at Stage I, and two at Stage 2) and six retellings of Saint George (at four different times, two at Stage I, and two at Stage 2) (see Comajoan, 2001, 2005a for details on the procedure).

All verbal forms produced in past context were coded for the verbal morphology (present, periphrastic past, imperfect, present perfect, and other) and aspectual category (state, activity, accomplishment, achievement). For the study of emergence of morphology, the analysis consisted of the verbal forms of the tasks within which the first io occurrences of periphrastic past and imperfect occurred. Highfrequency statives (ser-estar, "be," haver, "have, auxiliary" tenir, "have," tenir que, "have to") were not included in the analysis of emergence of morphology, because the inflection of these predicates distorts the general pattern of inflection of states (Bardovi-Harlig, 2000; 2005).

The analysis of the state category consisted on identifying all state predicates in the data, coding them for verbal morphology, and analyzing them in a token count, a type count, and a ratio of past morphology forms (periphrastic past, imperfect) over the total number of inflected tokens. The difference between a token count and a type count is that the former takes into account all verbal forms irrespective of the number of times they were used (e.g., when a learner used io times the form era "was-imperfective," it is counted to times), whereas a type count includes only different verbal forms.

\section{Results}

The emergence of periphrastic past and imperfect did not occur exclusively in the categories predicted by the aspect hypothesis (Table 2). For instance, in the narrative retellings, within a period of approximately

ners of Catalan as a foreign language. Three of the learners were studied for a period of three months (approximately one university semester in the United States). The other three were studied for a period of seven months (two semesters). Only data from the learners who participated in the complete study are presented. The pseudonyms for the learners are Danicl, Barbara, and Robert. See Comajoan (20or) for details on the participants and data collection procedure and analysis. 
three months, Barbara used periphrastic past forms in all four types of lexical predicates.

TABLE 2. First to tokens of periphrastic past (PerP) and imperfect (Imp) in narrative retellings and conversations, Comajoan (200I; 2005b).

\begin{tabular}{cccc}
\hline Daniel & Barbara & Robert & Total \\
\hline Ach Acc Act St & Ach Acc Act St & Ach Acc Act St & Ach Acc Act St \\
\hline
\end{tabular}

Narrative retellings

\begin{tabular}{|c|c|c|c|c|c|c|c|c|c|c|c|c|c|}
\hline & $(1 ; 17-5 ; 27)$ & & & I8-2; & & & & & & & & & \\
\hline PerP & $\begin{array}{lcc}6 & 3 & 1 \\
(1 ; 17-7 ; 10)\end{array}$ & o & & ;18-2 & & 5 & & & & & & 0 & 5 \\
\hline ח & - 06 & 5 & 2 & 0 & 6 & 8 & 0 & 5 & o & & & & \\
\hline
\end{tabular}

Conversations

\begin{tabular}{|c|c|c|c|c|c|c|c|c|c|c|c|c|c|c|c|c|}
\hline \multicolumn{4}{|c|}{$(1 ; 24)$} & \multicolumn{5}{|c|}{$(1 ; 25-4 ; 5)$} & \multicolumn{4}{|c|}{$(1 ; 17-31)$} & \multirow[b]{2}{*}{13} & \multirow[b]{2}{*}{14} & \multirow[b]{2}{*}{9} & \\
\hline PerP & & $\begin{array}{c}0 \\
24-3\end{array}$ & & I & & $\begin{array}{r}5 \\
25-\end{array}$ & $\begin{array}{c}\mathbf{I} \\
2 \mathrm{I}\end{array}$ & 3 & 4 & $\begin{array}{c}9 \\
1 ; 17\end{array}$ & $\begin{array}{r}4 \\
3 \text { I }\end{array}$ & I & & & & 5 \\
\hline $\operatorname{Imp}$ & 3 & 2 & 2 & 4 & 1 & 4 & 4 & II & 0 & 3 & 6 & 2 & 4 & 9 & 12 & 17 \\
\hline
\end{tabular}

Note. The numbers in parentheses refer to the dates in months and days in which the tasks containing the first 10 occurrences of periphrastic past or imperfect morphology were produced (e.g., Daniel produced the first 10 tokens of periphrastic past in retellings between $1 ; 17$ and $5 ; 27$ ).

Despite the variability in the data, the general pattern was for periphrastic past forms to occur in telic predicates and for the imperfect forms to emerge in atelic predicates. For instance, in the narrative retellings, the distribution of periphrastic past forms in the different lexico-aspectual categories was: 2I (achievements), to (accomplishments), 5 (activities), and 5 (states). In contrast, the distribution of imperfect forms in the retellings was: $\mathrm{z}$ (achievements), 5 (accomplishments), 12 (activities), and 20 (states). Focusing on imperfect morphology, the data indicate that it was not used exclusively in atelic predicates, but the trend was for the imperfect to be less spread to other categories than the periphrastic past.

The emergence of imperfect took longer than the emergence of periphrastic past, as indicated by the number of months and days to elicit the first to tokens of each type of morphology. For instance, in the retelling data, Daniel produced to periphrastic past forms within a period of more than 5 months, but it took him more than 7 months to 
produce $\mathrm{II}$ imperfect forms. The period of emergence of periphrastic past and imperfect for Barbara and Robert was similar, and in one instance (Barbara, in conversations), the period of emergence of imperfect was shorter than the period of emergence of periphrastic past. When comparing how past morphology emerged in the two types of narrative tasks, the results show that the emergence of imperfect in the conversations was more varied across lexical categories than in the retellings. For instance, in the retellings, imperfect morphology was not used at all in five instances (achievements and accomplishments in Daniel's data, accomplishments in Barbara's data; achievements and activities in Robert's data). In contrast, imperfect morphology was not used in the conversations only in one instance (achievements in Robert's data).

Previous studies have not generally distinguished between highfrequency and nonhigh-frequency statives, and thus it has not been possible to study to what extent the inflection of statives and imperfect was restricted to a small number of lexical items (Bardovi-Harlig, 2005). The data in Table 2 excluded the high-frequency statives, and imperfect morphology still concentrated in the state category, which can be taken as evidence of early spread of imperfect toward a larger group of stative predicates.

In order to further investigate the inflection of stative predicates and the emergence and development of imperfect morphology, all stative predicates in the retellings and conversations were analyzed (Appendix, Tables $\mathrm{i}-3$ ). The data in the Modern Times and Saint George retellings show that the three learners used periphrastic past and imperfect forms in a limited number of stative verbs (high-frequency statives and up to ro other stative types). In the Modern Times task, the three learners never used periphrastic past or imperfect in more than 6 types, and in the Saint George retelling, imperfect in statives was used in to types. In contrast, in the conversations, the lexical variety of the stative category was higher than in the retellings (25 was the highest number of types inflected in the imperfect).

The comparison of the number of state types inflected in the periphrastic past and the imperfect in the retellings and conversations is problematic, because the conversations were longer than the retellings; and, consequently, the conversations included more opportunities for the inflection of morphology. In order to compare the inflection of states in the two types of narrative data, a ratio of state tokens over the total number of inflected tokens was calculated. The ratio data from Tables $1-3$ in the Appendix are presented in Table 3. 
TABLE 3. Ratio of periphrastic past (PerP) and imperfect (Imp) inflection over the total number of inflected state tokens in state predicates (based on Tables $1-3$ in the Appendix).

\begin{tabular}{|c|c|c|c|c|c|c|}
\hline & \multicolumn{2}{|c|}{ Daniel } & \multicolumn{2}{|c|}{ Barbara } & \multicolumn{2}{|c|}{ Robert } \\
\hline & Stage 1 & Stage 2 & Stage I & Stage 2 & Stage 1 & Stage 2 \\
\hline \multicolumn{7}{|c|}{ Modern Times retellings } \\
\hline PerP & - & 5.1 & 2.5 & 2.9 & 2.0 & 0.4 \\
\hline $\operatorname{Imp}$ & $\ldots$ & S.I & 1.2 & 1.4 & 3.8 & 6.9 \\
\hline \multicolumn{7}{|c|}{ Saint George retellings } \\
\hline PerP & - & 0.5 & 2.5 & 1.5 & - & - \\
\hline $\operatorname{Imp}$ & - & 6.5 & 6.4 & 13.2 & 15.7 & 15.7 \\
\hline \multicolumn{7}{|c|}{ Conversations } \\
\hline PerP & 0.4 & $4 \cdot 1$ & 0.7 & 3.4 & 0.6 & 3.2 \\
\hline Imp & 2.7 & 27.7 & 9.5 & 27.7 & 6.3 & 24.7 \\
\hline
\end{tabular}

Despite the variability in the results (e.g. imperfect ratios of 6.5, 13.2, and 15.7 at Stage 2 in the Saint George retellings from the three participants, respectively), the data in Table 3 show that forms in stative predicates were commonly inflected in the imperfect: The ratios of imperfect were higher than the ratios of periphrastic past in all tasks and learners (except for Barbara in Modern Times). Regarding the development of morphology from Stage I to Stage 2, the ratio of periphrastic past/imperfect forms in state predicates increased in all cases except for the use of periphrastic past by Robert in the Modern Times task and the use of periphrastic past by Barbara in the Saint George retellings.

The ratios of imperfect in the conversation data were higher than in the retelling data. All three learners produced a ratio of imperfect use in state predicates in the conversations that ranged between 24.7 and 27.7. Overall, the data in Table 3 can be positioned along a continuum from lower to higher use of imperfect in the different tasks used in this study: Modern Times (low ratios), Saint George (medium rations), and conversations (high ratios).

\section{Discussion}

The results from this study showed that the inflection of past morphology by the three learners was variable, but the following patterns in the acquisition of the imperfect were found: Imperfect 
morphology emerged later than periphrastic past; imperfect morphology was mostly found in stative predicates, and it began to spread to nonhigh-frequency statives and telic predicates; and the ratio of inflection of states in the imperfect was higher in the conversations than in the retellings. The discussion of these results focuses on explanations of the data that go beyond description (Andersen, 2002); namely, the learners' linguistic profile, and the specificity of the $\mathrm{L}_{2}$ acquisition of imperfect morphology.

All three learners in this study had extensive experience learning other languages with perfective-imperfective morphology (Spanish and French), which is likely to have influenced their acquisition of Catalan. For instance, they produced periphrastic past and imperfect forms earlier than in previous studies, and they used past morphology more appropriately than other beginning learners (Comajoan \& Pérez Saldanya, 2003, 2005). However, they did not produce early nonprototypical uses of past morphology. The results on emergence and development of past morphology in the acquisition of Catalan by the learners in the current study show that different populations of learners may acquire past morphology at a different rate (e.g., earlier inflection of morphology), but they follow similar routes. However, it could be argued that the learners in this study were not true beginning learners, because they had extensive knowledge of other languages; and thus their interlanguage differed from the typical beginner learner in instructed environments. For this reason, further research needs to contrast the results from this study with data on the earliest stages of acquisition of second and third languages (Salaberry, 2005 is a first attempt at examining $\mathrm{L}_{3}$ acquisition but for advanced learners) and investigate how multiple tense-aspect systems interact in the acquisition of morphology and to what degree multilingual acquisition (by learners with knowledge of more than one $\mathrm{L}_{2}$ ) differs or resembles second language acquisition (Cenoz, 2000; Hammarberg, 2001).

A cognitive explanation within prototype and grammaticalization theory can account for the general patterns found in the data for this study (Andersen \& Shirai, 1994, 1996; Giacalone-Ramat, 1995, 2002; Shirai, 2002; Shirai \& Andersen, 1995). The associations of perfective morphology with telicity, and imperfective morphology with atelicity stem from the association of one type of morphology with one type of meaning, the most prototypical one (i.e., completive/resultative for perfective; stative for imperfective, Andersen, 2002; Bybee et al., 1994). In this view, learners first acquire prototypical combinations of formfunction and later develop nonprototypical ones. These combinations are not categorical, as evidenced in the results from the current study (verbs in stative predicates were inflected both in the periphrastic past and the imperfect, see Tables $1-3$ in the Appendix). Thus, the learners' 
interlanguage does not follow the one-to-one principle (one form = one function, Andersen, 1993) in the sense of using exclusively one type of inflection for one meaning, but rather, they associate specific tense-aspectual characteristics with prototypical predicates. In contrast, in the interlanguage of more advanced learners - who are trying to acquire the pragmatic, semantic, and syntactic characteristics of the $\mathrm{L}_{2}$ tense-aspect system - the one-to-one principle may be more evident (Giacalone Ramat, 1995, p. 300).

Salaberry (2000) argued that beginning learners of Spanish use perfective morphology as a default marker of past tense across all lexicalaspectual categories and that they associate perfective morphology with pastness rather than telicity (tense as a default marker). The main difference between the participants in the studies that support the aspect hypothesis and adopt a prototype theory perspective (e.g., Giacalone Ramat, 2002) and Salaberry (2000) is that of learning environment. The learners in Giacalone Ramat's studies learned Italian in natural environments, whereas Salaberry's studies were U.S. classroom studies. In the current study, perfective morphology was not used across all four lexical categories in similar proportions, which suggests that learners were not using perfective morphology exclusively as a default marker (Camps, 2005; Comajoan, 2005b). In sum, the current results provide evidence that both natural and tutored learners identify telicity as the prototype for past morphology in the beginning stages of acquisition.

In regard to the use of perfective morphology as a default marker in the early stages of acquisition, further research needs to investigate the definitions of "beginning" stages of $\mathrm{L}_{2}$ acquisition and "default" marker. Current use of labels such as "beginning stages" and "beginner learner" vary from study to study and make it difficult to establish comparisons and make claims about emergence of morphology. It is likely that the "beginner" learners of the current study, those in Salaberry (2000), and the untutored learners in Klein, Dietrich \& Noyau (1995) may be affected differently by a variety of learning environment and personal characteristics (e.g., motivation, language background, and instruction) and display different language development. For instance, in a study of $\mathrm{L}_{2}$ English, Collins (2002) found that beginner learners did not mark differently accomplishments and achievements; but in a further study, which included learners from a lower proficiency level, the use of English simple past was higher in achievements than accomplishments, indicating that the association of punctuality and perfectivity is most relevant in the earliest stages of acquisition. Further research should investigate similar groups, environments, and elicitation tasks or, in case they are not possible to control, adopt research methodologies that take into account variation (e.g., variationist approaches used in sociolinguistics). 
As far as the concept of "default," on the one hand, it is reminiscent of the notion of prototypicality, and an explanation of the data based on a default marker can be accommodated within explanations of the aspect hypothesis from the perspective of prototypicality theory. On the other hand, the use of a default marker may be understood as evidence against the aspect hypothesis when the focus is on the use of the marker across lexical categories in the beginning stages of acquisition (e.g., Salaberry, 2000). However, as shown in Rocca (2002), the use of a default marker does not imply lack of development and spread of morphology, but rather the opposite. For instance, in the acquisition of $\mathrm{L}_{2}$ Italian imperfect (by $\mathrm{L}_{1}$ children), imperfect emerged in states, but as it spread to activities, its use in states decreased. In turn, as inflection of imperfect in states decreased, the inflection of states in perfective form (passato prossimo, past participle) increased and became the "default option for states" (Rocca, 2002, p. 279). It is unclear what was really meant by "default option," because the data in Rocca (2002) did not show use of perfective forms exclusively in states, but the examples indicated that the learners first inflected a stative (volere, "to want") in the imperfect, and, afterward, as imperfect spread to activities, the same predicate was inflected in perfective form (past participle) in an imperfective context.

The findings regarding the order of acquisition of perfective and imperfective morphology (i.e., late acquisition of imperfective morphology) are related to the multidimensionality and markedness of imperfect morphology (Ayoun, 2004, 2005; Bernini 1990, BardoviHarlig, 2005; Kihlstedt, 2002; Noyau, 2002; Salaberry, 2005). Imperfect morphology has temporal, aspectual, and modal functions, all of which may become obstacles for early $L_{2}$ acquisition, because learners in the initial stages of acquisition tend to associate prototypical meanings to specific morphology forms. Beginning learners perceive that perfective morphemes mark completion or endpoint and that imperfective morphemes mark durativity or background information, and although the input contains instances of the multiple functions of the imperfect, beginning learners may not notice and process them. Consequently, imperfect morphology emerges later, and its period of development from prototypical to nonprototypical usage is longer than for the periphrastic past. In this view, imperfect morphology requires from the learner more attention to input and higher cognitive demands to process the forms and produce them. This process is further complicated because perfective forms are readily available, less ambiguous, and congruent (i.e., they combine past temporality, completion, and saliency). The concomitance of $\mathrm{L}_{2}$ past verbal forms (perfective and imperfective) and functions (completion, duration, and discourse grounding, among others) does not necessarily have to be 
categorical (one-to-one) but probabilistic, in the sense that the confluence of factors (e.g., text type, narrative style, linguistic background, and cognitive demand) will trigger a specific type of morphology. ${ }^{12}$

The acquisition of $\mathrm{L}_{2}$ imperfect morphology in Romance is also related to the markedness status of imperfective morphology in the LI and $\mathrm{L}_{2}$. The markedness relationship between perfective and imperfective morphology is not straightforward for two reasons. Crosslinguistically, it is too difficult to identify what is marked and what is unmarked due to the variety of tense-aspect systems (Dahl, 1985); and the degree of markedness can vary according to semantic, morphological, and frequency tests (Comrie, 1976). However, in specific language groups, such as the Romance family, perfective is considered to be unmarked and imperfective marked (see also Givón, 1995, p. 54; Smith, 1991, p. 14). ${ }^{13}$

The markedness relationship of perfective and imperfective morphology has been mostly studied within a typological approach that examines which tense-aspect categories receive marking and distinguishes between central and peripheral categories of tense-aspect (i.e., prototypicality). In Dahl's (1985) approach, central tense-aspect categories are marked obligatorily, but they surface morphologically in different manners depending on the specific language. Thus, the Catalan ( $\mathrm{L}_{2}$ ) and English $\left(\mathrm{L}_{1}\right)$ tense-aspect systems differ in two ways. Catalan has distinct perfective, imperfective, and progressive (estar - nt, "be -ing") morphology; whereas English only has perfective and imperfective-progressive morphology (be -ing). Second, perfective morphology in Catalan is periphrastic and imperfective morphology is inflectional; whereas the opposite occurs in English.

In their process of language acquisition, the learners in this study had to develop from an Lr system that shares the morphology of the perfective-imperfective contrast with progressive to an $\mathrm{L}_{2}$ system that makes a more refined distinction. In addition, the learners had to acquire an $\mathrm{L}_{2}$ morphological system in which the periphrastic and inflectional nature of the verbal morphology was the opposite of their LI. Furthermore, the learners had knowledge of another $\mathrm{L}_{2}$ system (Spanish) that shared some of the Catalan characteristics: The functions of Spanish pretérito and imperfecto are equivalent to the Catalan perfective and imperfective forms, but the Spanish forms are inflectional

12. See Li and Shirai (2000) for a probabilistic model of the acouisition of tense and aspect in English, Chinese, and Japanese.

13. Dahl $(1985,2000)$ refused to define the markedness relationship of the perfectiveimperfective opposition arguing that in most languages the markedness status of the two notions is not clear and that their relationship is far too complex in order to argue for a marked member and an unmarked one. However, Dahl clarified that this did not imply that both categories were equivalent. 
(not periphrastic). In sum, Catalan perfective forms share functional similarities with Spanish, but not their morphological form. On the other hand, Catalan and Spanish imperfect forms share form and function. Despite the similarities of form-function in Catalan and Spanish, the Catalan perfective forms emerged earlier than the imperfect forms, which suggests that the similarities in the two L2s of the learners were not as important as the differences between the $\mathrm{L}_{1} / \mathrm{L}_{2}$ systems and the marked nature of the imperfect. ${ }^{\mathrm{I} 4}$

Text types can also be analyzed in terms of markedness. Narratives are considered marked because their linguistic characteristics are different from everyday language (Fleischman, 1990, P. 4). For instance, retellings of movie narratives are commonly carried out in the historical present by native speakers even though they have past referentiality. $\mathrm{L}_{2}$ learners often use past tense morphology when they produce retellings, not being aware that the retelling is a specific text type with its own subtleties. Noyau (1984, 1990) argued that personal narratives, as opposed to fictional retellings, provided a richer picture of the learner's temporal system, because personal narratives, in addition to reference time, need to be related to speech time and provide more temporal switches. The data in the current study provide specific evidence of Noyau's argument, because the conversational narratives were richer lexically (the learners used more stative verbs) and morphologically (inflection was richer than in the retellings).

Previous research has begun to investigate the effect of task type on the acquisition of morphology, but so far it has only compared controlled tasks in cross-sectional designs focusing on intermediateadvanced learners, or it has examined the different proportions of perfective and imperfective morphology in different text types. For instance, Liskin-Gasparro (200o) investigated two types of narratives and found that the proportion of Spanish preterite and imperfect morphology in personal narratives was $40 \%$ and $60 \%$, respectively; whereas the proportions were the reverse for fictional retellings $(63 \%$ and $37 \%$, respectively). Salaberry $(2003)$ found a difference in the use of morphology in fictional and personal narratives, but the two types of narratives used by Salaberry can barely be considered different in terms of a personal or fictional narrative. The fictional one was based on a movie retelling, and the personal one was based on a narrative of

14. Crosslinguistically, perfective periphrastic forms are marked in contrast with perfective inflectional forms (Dahl, 1985 , p. 183). Further research needs to explore whether markedness of inflectional type has an effect in the $\mathrm{L}_{2}$ acquisition of morphology. For instance, is the acquisition of inflectional perfective forms (e.g., English simple past tense and Spanish pretérito) similar to the acquisition of noninflectional (i.e., periphrastic) perfective forms (e.g., Catalan periphrastic past, French passé composé, Italian passato prossimo, and German perfekt)? 
a person (not the learner) when he or she was $n$ or 12 years old. Salaberry acknowledged that the learner's choice of preterite or imperfect as a default tense marker could be due to the nature of the specific tasks, because the personal text began with Cuando (soy/fuilera/ser) niña de once o doce años, un dia ... "When (I am, I was-preterite be, I was-imperfect be, infinitive be) a girl aged eleven or 12, one day...," which may have triggered use of imperfect; whereas the fictional retelling began with Ayer una mujer joven $y$ bonita... "Yesterday a beautiful and young woman...." Further research needs to compare these results to elicited data in less controlled environments and in studies that provide more refined typologies of textual types (e.g., as in Bronckart \& Bourdin, 1993).

The multidimensionality of imperfect is closely related to two additional factors: its main discourse functions (mark background information and switch temporal reference) and participant interaction. Imperfect forms are anchored to time references in other sections of discourse (i.e., they are anaphoric), and learners at initial states, when discourse organization through morphology is minimal, have difficulty at building textured narratives and switching temporal reference. Wiberg (2002), in a study of future temporality, found that advanced Swedish learners of Italian made fewer switches in dialogues than native speakers, and that native speakers could mix temporal references (past, present, and future) with better ease than learners. Thus, narratives in conversations are likely to include more imperfect forms than other discourse types, because there will be more opportunities for switch-reference triggered by the interlocutor. In this respect, it is not surprising that the conversation data in the current study provided more instances of imperfect than the retelling data and that L 2 morphology emerged and developed in contexts in which the narrative functions of tense and aspect developed and grammaticalized historically. In other words, in the grammaticalization of the meaning of past, "the specifically narrative functions of tense and aspect developed as motivated pragmatic responses to the conditions of narrative performance in interactive oral contexts" (Fleishman, 1990, p. 7, emphasis added).

Finally, an investigation of the acquisition of imperfect should not only study how forms emerge and in what aspectual predicates, but also their discourse functions. Previous research has confirmed that $\mathrm{L}_{2}$ imperfect forms mark background information (Bardovi-Harlig, 2000; Comajoan, 2005a; Giacalone Ramat, 2002), but further research should investigate the different ways of marking background. For instance, in a detailed analysis, Kihlstedt (2002) investigated the use of French imparfait by Swedish advanced learners and found that they first used imparfait for total overlap, followed by habitual imperfect and short 
overlap imperfect. ${ }^{\text {is }}$ Very few learners used imperfect "on the limits" (with punctual events). The current study did not examine the clausal functions of the imperfect forms produced by the learners, but some of the lexical items that were inflected in the imperfect do not easily lend themselves to habitual readings (e.g., semblar "seem," pensar, "think," conèixer "meet").

\section{CONCLUSION}

The results from this study add to the growing body of research in the acquisition of perfective and imperfective morphology in Romance languages. Whereas early studies in the aspect hypothesis focused on whether the lexico-semantic characteristics of predicates could explain the acquisition of past morphology, current research focuses on specific lexical categories and the links between semantics, morphology, and discourse. The $\mathrm{L}_{2}$ Catalan data from this study have confirmed the results from studies in the acquisition of other Romance languages, and, in addition, they have provided some new findings regarding the association between state predicates and imperfect morphology. Specifically, the lexical diversity of the category of states was higher in conversations than in retellings, which suggests that type of task and speaker interaction contribute to the use of a larger number of stative predicates and, hence, imperfect morphology. This study has also argued for an explanation of the difficulty of the imperfect based on its marked status. The markedness explanation can prove fruitful, because it encompasses the multiple dimensions of the process of $\mathrm{L}_{2}$ acquisition in Romance languages, such as grammaticalized morphology (perfective vs. imperfective), grammaticalized meaning (prototype vs. periphery), type of morphology (periphrastic vs. inflectional), and text type (narratives: retellings vs. conversations). All these dimensions play a role in the acquisition of past morphology, and further $\mathrm{L}_{2}$ research must continue to examine how they interact with each other and accommodate them within one theoretical framework.

\section{LLORENÇ COMAJOAN UNIVERSITAT DE BARCELONA}

15. Kihsltedt (2002) classified imperfect forms into four categories. In imperfect of total overlap, the event time overlaps with reference time. In habitual imperfect, repeated occurrences of the events take place in the reference time (and may not overlap completely with reference time). In imperfect of short overlap, the situation is ongoing only for a short reference time (and is never habitual). Finally, imperfect "on the limits" is the use of imperfect with punctual verbs. 


\section{REFERENCEŚ}

ANDERSEN, R. (1991). Developmental sequences: The emergence of aspect marking in second language acquisition. In C. A. Ferguson \& T. Huebner (Eds.), Second language acquisition and linguistic theories (pp. 305-324). Amsterdam: Benjamins.

ANDERSEN, R. (I993). Four operating principles and input distribution as explanations for underdeveloped and mature morphological systems. In K. Hyltenstam \& A. Viborg (Eds.), Progression and regression in language (pp. 309-339). New York: Cambridge University Press.

ANDERSEN, R. (2002). The dimensions of pastness. In R. Salaberry \& Y. Shirai (Eds.), The Lz acquisition of tense-aspect morphology (pp. 79-105). Philadelphia: Benjamins.

ANDERSEN, R., \& SHIRAl, Y. (1994). Discourse motivations for some cognitive acquisition principles. Studies in Second Language Acquisition, 16, 135-156.

ANDERSEN, R, \& SHIRAI, Y. (1996). The primacy of aspect in first and second language acquisition: The pidgin-creole connection. In W. C. Ritchie \& T. K. Bhatia (Eds.), Handbook of second language acquisition (pp. 527-570). San Diego, CA: Academic Press.

AYOUN, D. (200I). The role of negative and positive feedback in the second language acquisition of the passé composé and imparfait. The Modern Language Journal, 85, 226-243.

Ayoun, D. (2004). The effectiveness of written recasts in the second language acquisition of aspectual distinctions in French: A followup study. The Modern Language Journal, 88, 3I-55.

Ayoun, D. (2005). The acquisition of tense and aspect in $\mathrm{L}_{2}$ French from a Universgal Grammar perspective. In D. Ayoun \& R. Salaberry (Eds.), The acquisition of tense-aspect morphology in the Romance languages (pp. 79-127). Philadelphia: Benjamins.

BadiA, A. M. (1994). Gramática de la llengua catalana. Barcelona, Spain: Enciclopedia Catalana.

Bardovi-HaRliG, K. (2000). Tense and aspect in second language acquisition: Form, meaning, and use. Malden, MA: Blackwell.

BARDOVI-HARLIG, K. (2005). Tracking the illusive imperfect in adult $\mathrm{L}_{2}$ acquisition. In P. Kempchinsky \& R. Slabakova (Eds.), Aspectual inquiries (pp. 397-419). Berlin: Springer.

$\mathrm{BEL}, \mathrm{A}$. (2001). Teoria lingüistica $i$ adquisició del llenguatge. Anàlisi comparada dels trets morfològics en català $i$ en castellà [Linguistic theory and language acquisition: comparative analysis of morphological features in Catalan and Spanish]. Barcelona, Spain: Institut d'Estudis Catalans.

BERNINI, G. (1990). L'acquisizione dell'imperfetto nell'italiano lingua 
seconda [The acquisition of imperfect in Italian as a second language]. In E. Banfi \& P. Cordin (Eds.), Storia dell'italiano e forme dell'italianizzazione (pp. 157-180). Rome: Bulzoni,

BINNICK, R. I. (I991). Time and the verb: $A$ guide to tense and aspect.

New York: Oxford University Press.

BLASCO, E. (1982). Entorn dels temps verbals i els conceptes d'aspecte', 'aktionsart' i 'estadi' en català [On verbal tenses and the concepts of 'aspect', 'aktionsart' and 'stage' in Catalan]. Els Marges, 25, 109-114. BrEs, J. (Ed.). (2003). Temps et co(n)texte. Langue Française, 138.

BRONCKART, J. P., \& BOURDIN, B. (I993). L'acquisition des valeurs des temps des verbes: Étude comparative de l'allemand, du basque, du catalan, du français et de l'italien [The acquisition of the values of verbal tenses: Comparative study of German, Basque, Catalan, French, and Italian]. Langue Française, 93, 102-I24.

Brucart, J. M., \& RigaU, G. (1997). Le système des temps verbaux en espagnol et en catalan. Travaux de Linguistique, 3I, 79-103.

Bybee, J., PERKINS, R., \& PAgliucA, W. (1994). The evolution of grammar. Tense, aspect, and modality in the languages of the world. Chicago: The University of Chicago Press.

CAMPS, J. (2002). Aspectual distinctions in Spanish as a foreign language: The early stages of oral production. International Review of Applied Linguistics, 40, 179-210.

Camps, J. (2003, October). Tense-aspect morphology in Spanish as a foreign language: The case of state verbs. Paper presented at the 6th Conference on $\mathrm{L}_{1}$ and $\mathrm{L}_{2}$ Acquisition of Spanish and Portuguese, Albuquerque, University of New Mexico.

CAMPS, J. (2005). The emergence of the imperfect in Spanish as a foreign language: The association between imperfective morphology and state verbs. Intemational Review of Applied Linguistics, 43, 163-192.

CENOZ, J. (2000). Research on multilingual acquisition. In J. Cenoz \& U. Jessner (Eds.), English in Europe: The acquisition of a third language (pp. 39-53). Clevedon, England: Multilingual Matters.

Chaplin, C. (Producer and Director). (1936). Modem Times [Videotape].

(Available from Borders Books and Music).

Collins, L. (2002). The roles of $\mathrm{L}_{1}$ influence and lexical aspect in the acquisition of temporal morphology. Language Learning, s2, 43-94. COMAJOAN, L. (200I). The acquisition of Catalan La past morphology: Evidence for the aspect and discourse bypotbeses. Unpublished doctoral dissertation, Indiana University, Bloomington.

COMAJOAN, L. (2005a). The acquisition of perfective and imperfective morphology and the marking of discourse grounding. In D. Ayoun \& R. Salaberry (Eds.), The acquisition of tense-aspect morphology in the Romance languages (pp. 36-77). Philadelphia: Benjamins.

COMAJOAN, L. (2005b). The early $\mathrm{L}_{2}$ acquisition of past morphology: 
Perfective morphology as a default marker or aspectual marker? In D. Eddington (Ed.), Selected proceedings of the 6 th Conference on the Acquisition of Spanish and Portuguese as First and Second Languages (pp. 31-43). Somerville, MA: Cascadilla Press.

COMAJOAN, L, \& PÉREZ SALDANYA, M. (2003). Gramaticalització $i$ adquísició de llengües: l'adquisició de la morfologia de passat en aprenents del català com a segona llengua [Grammaticalization and language acquisition: The acquisition of past morphology in learners of Catalan as a second language]. Caplletra, 35, 123-I52.

COMAJOAN, L., \& PEREZ SALDANYA, M. (2005). Grammaticalization and language acquisition: Interaction of lexical aspect and discourse. In D. Eddington (Ed.), Selected proceedings of the 6th Conference on the Acquisition of Spanish and Portuguese as First and Second Languages (pp, 44-5s). Somerville, MA: Cascadilla Press.

COMrie, B. (1976). Aspect. New York: Cambridge University Press.

Comrie, B. (1985). Tense. New York: Cambridge University Press.

CORTÉS, M., \& VILA, I. (I99I). Uso y función de las formas temporales en el habla infantil [Use and function of tense forms in children's speech]. Infancia y Aprendizaje, 53, 17-43.

DAHL, Ö. (1985). Tense and aspect systems. New Yorfk: Blackwell.

DAHL, Ö. (2000). The tense-aspect systems of European languages in a typological perspective. In O. Dahl (Ed.), Tense and aspect in the languages of Europe (pp. 3-25). New York: De Gruyter.

De Miguel, E. (1999). El aspecto léxico. In I. Bosque \& Violeta Demonte (Eds.), Gramática descriptiva de la lengua española (Vol. 2, pp. 2977-3060). Madrid, Spain: Espasa.

DieTrICH, R., KLEIN, W., \& NOYAU, C. (1995). The acquisition of temporality in a second language. Philadelphia: Benjamins.

DowTY, D. (1979). Word meaning and Montague Grammar. Dordrecht, The Netherlands: Reidel.

EsPunYA, A. (1996). Progressive structures of English and Catalan. Unpublished doctoral dissertation, Universitat Autònoma de Barcelona, Spain.

Fleischman, S. (1990). Tense and narrativity: From medieval performance to modern fiction. Austin, TX: University of Texas Press.

GARCÍA FERnANDEZ, L., \& CAMUS, B. (Eds.). (2003). El pretérito imperfecto. Madrid: Gredos.

GiaCALONE-RAMAT, A. (I992). Grammaticalization processes in the area of temporal and modal relations. Studies in Second Language Acquisition, I4, 297-322.

GIACALONE-RAMAT, A. (1995). Tense and aspect in learner Italian. In P.M. Bertinetto, V. Bianchi, O. Dahl, \& M. Squartini (Eds.), Temporal reference: Aspect and actionality: Vol. 2. Typological perspectives (pp. 289-309). Turin, Italy: Rosenberg \& Sellier. 
Giacalone-RAmat, A. (2002). How do learners acquire the classical three categories of temporality? Evidence from $\mathrm{L}_{2}$ Italian. In $\mathrm{R}$. Salaberry \& Y. Shirai (Eds.), The $L_{2}$ acquisition of tense-aspect morphology (pp. 221-247). Philadelphia: Benjamins.

Grvón, T. (1995). Functionalism and grammar. Philadelphia: Benjamins. HammarberG, B. (200I). Roles of $\mathrm{L}_{1}$ and $\mathrm{L}_{2}$ in $\mathrm{L}_{3}$ production and acquisition. In J. Cenoz, B. Hufeisen, \& U. Jessner (Eds.), Crosslinguistic influence in third language acquisition: Psycholinguistic perspectives (pp. 2I-41). Clevedon, England: Multilingual Matters.

HOWARD, M. (2004). On the interactional effect of linguistic constraints on interlanguage variation: The case of past time marking. International Review of Applied Linguistics, 42, 319-334.

KIHLSTEDT, M. (2002). Reference to past events in dialogue: The acquisition of tense and aspect by advanced learners of French. In R. Salaberry \& Y. Shirai (Eds.), The Lz acquisition of tense-aspect morphology (pp. 323-361). Philadelphia: Benjamins.

LACA, B. (1995). Une question d'aspect: À propos des périphrases progressives en catalan [A question of aspect: Regarding the progressive periphrases in Catalan]. Estudis de lingüistica i filologia oferts a Antoni M. Badia i Margarit, 495-509. Barcelona, Spain: Universitat de Barcelona and Publicacions de l'Abadia de Montserrat.

LI, P., \& SHIRAI, Y. (2000). The acquisition of lexical and grammatical aspect. New York: Mouton de Gruyter.

LISKIN-GASPARRO, J. (2000). The use of tense-aspect morphology in Spanish oral narratives: Exploring the perceptions of advanced learners. Hispania, 83, 830-844.

Mrт7wоCH, A. (1991). In deference to Vendler's achievements. Belgian Journal of Linguistics, 6, 71-85.

mas, M., Melcion, J., Rosanas, R., \& Vergés, M. H. (I99I). Curs de català per a estrangers: Digui Digui [Course of Catalan for foreigners: Digui Digui]. Barcelona, Spain: Publicacions de l'Abadia de Montserrat.

Montrul, S., \& SalaberRy, R. (2003). The development of tense/ aspect morphology in Spanish as a second language. In B. A. Lafford \& R. Salaberry (Eds.), Spanish second language acquisition (pp. 47-73). Washington, DC: Georgetown University Press.

NOYAU, C. (1984). The development of menas for temporality in French by adult Spanish-speaking speakers: Linguistic devices and communicative capacities. In G. Extra \& M. Mittner (Eds.), Studies in second language acquisition by adult immigrants: Proceedings of the ESF/AILA Symposium beld on the gth of August 1984 in Brussels (pp. I13-137). Tilburg, The Netherlands: Tilburg University.

NOYAU, C. (1990). The development of means for temporality in the unguided acquisition of $\mathrm{L}_{2}$ : Cross-linguistic perspectives. In $\mathrm{H}$. W. 
Dechert (Ed.), Current trends in European second language acquisition research (pp. 143-170). Philadelphia: Multilingual Matters. NOYAU, C. (2002). Temporal relations in learner varieties: Grammaticalization and discourse construction. In R. Salaberry \& Y. Shirai (Eds.), The L2 acquisition of tense-aspect morphology (pp. 107-128). Philadelphia: Benjamins.

PEREZ SALDANYA, M. (1996). Gramaticalització i reanàlisi: El cas del perfet perifràstic català [Grammaticalization and reanalyisis: The case of the Catalan periphrastic perfective]. In A. Schönberger \& T. D. Stegmann (Eds.), Actes del desè col.loqui de llengua i literatura catalanes Vol. I (pp. 71-107), Barcelona, Spain: Publicacions de l'Abadia de Montserrat.

Pérez Saldanya, M. (1998). Del llatí al català. Morfosintaxi verbal històrica [From Latin to Catalan: Historical verbal morphosyntax]. Valencia, Spain: Universitat de València.

PÉREZ SALDANYA, M. (2002). Les relacions temporals i aspectuals [Tense and aspect relationships]. In J. Solà, M. R. Lloret, J. Mascaró, \& M. Pérez Saldanya (Eds.), Gramàtica del català contemporari Vol. 3 (pp. 2567-2662). Barcelona, Spain: Empúries.

RocCA, S. Lexical aspect in child second language acquisition of temporal morphology: A bidirectional study. In R. Salaberry \& Y. Shirai (Eds.), The L2 acquisition of tense-aspect morphology (pp. 221-248). Philadelphia: Benjamins.

RoJo, G., \& VEIGA, A. (1999). El tiempo verbal. Los tiempos simples. In I. Bosque \& V. Demonte (Eds.), Gramática descriptiva de la lengua española (Vol. 2, pp. 2867-2934). Madrid, Spain: Espasa.

SALABERRY, R. (2000). The development of past tense morphology in $\mathrm{L}_{2}$ Spanish. Philadelphia: Benjamins.

SALABERRY, R. (2003). Tense aspect in verbal morphology. Hispania, $86,559-573$.

SALABERRY, R. (2005). Evidence for transfer of knowledge of aspect from $\mathrm{L}_{2}$ Spanish to $\mathrm{L}_{3}$ Portuguese. In D. Ayoun \& R. Salaberry (Eds.), The acquisition of tense-aspect morphology in the Romance languages (179-2ro). Philadelphia: Benjamins.

SAlABERrY, R., \& AYOUN, D. (2005). The development of $\mathrm{L}_{2}$ tenseaspect in the Romance languages. In D. Ayoun \& R. Salaberry (Eds.), The acquisition of tense-aspect morphology in the Romance languages (Pp. I-33). Philadelphia: Benjamins.

Serra, M., Serrat, E., Bel, A., \& Aparici, M. (2000). La adquisición del lenguaje. Barcelona, Spain: Ariel.

SHIRAI, Y. (2002). The prototype hypothesis of tense-aspect acquisition in second language. In R. Salaberry \& Y. Shirai (Eds.), The $L_{2}$ acquisition of tense-aspect morphology (pp. 455-478). Philadelphia: Benjamins. 
SHIRA1, Y, \& ANDERSEN, R. (1995). The acquisition of tense-aspect morphology: A prototype account. Language, 7I, 743-762.

SMITH, C. (1997). The parameter of aspect (2nd ed.). Boston: Kluwer.

VENDLER, Z. (1967). Verbs and times, In Z. Vendler (Ed.), Linguistics and philosophy (pp. 97-121). Ithaca, NY: Cornell University Press. (Reprinted from Philosophical Review, 1957, 66, 143-160).

VERKUYL, H. J. (I993). A theory of aspectuality. New York: Cambridge University Press.

VINYES, J., \& RIFÀ, F. (1986). La llegenda de Sant Jordi [The legend of Saint George]. Barcelona, Spain: La Galera.

WEIST, R. (2002). The first language acquisition of tense and aspect: A review. In R. Salaberry \& Y. Shirai (Eds.), The $L_{2}$ acquisition of tense-aspect morphology (pp. 2i-78). Philadelphia: Benjamins.

WhEELER, M., YATES, A., \& DOLS, N. (1999). Catalan. A comprehensive grammar. New York: Routledge.

WIBERG, E. (2002). Information structure in dialogic future plans: A study of Italian native speakers and Swedish preadvanced and advanced learners of Italian. In R. Salaberry \& Y. Shirai (Eds.), The $L_{2}$ acquisition of tense-aspect morphology (pp. 285-322). Philadelphia: Benjamins. 


\section{APPENDIX}

TABLE 1 . Inflection of state predicates in the Modern Times retellings.

\begin{tabular}{|c|c|c|c|c|c|c|}
\hline & Dan & iel & Bart & para & Ro & pert. \\
\hline & Stage 1 & Stage 2 & Stage I & Stage 2 & Stage 1 & Stage 2 \\
\hline Present & 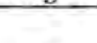 & & & & & \\
\hline baver "existential be" & 7 & 3 & 6 & 5 & I & 0 \\
\hline estar "be" & 3 & 2 & 0 & 0 & 1 & 1 \\
\hline ser "be" & 2 & 8 & 3 & 5 & I & 0 \\
\hline tenir "have" & 0 & 2 & 7 & 5 & I & $\mathrm{O}$ \\
\hline pensar "think" & I & 0 & 0 & 0 & 0 & 0 \\
\hline veure "see" & I & 3 & I & 0 & 0 & 0 \\
\hline poder "can" & I & 2 & 0 & 0 & o & 0 \\
\hline voler / querer "want" & I & I & I & 0 & I & 0 \\
\hline imaginar-se "imagine" & I & 0 & 0 & 0 & $\mathrm{O}$ & 0 \\
\hline semblar "seem" & O & 0 & I & o & 0 & 0 \\
\hline recordar "remember" & 0 & O & 0 & 2 & 0 & 0 \\
\hline sentir-se "feel" & 0 & 0 & O. & I & 0 & 0 \\
\hline faltar "be left," "remain" & 0 & 0 & 0 & 1 & 0 & 0 \\
\hline agradar "like" & 0 & 0 & 0 & I & 0 & 0 \\
\hline estimar-se "love" & 0 & 0 & o & I & o & 0 \\
\hline necessitar "need" & 0 & 0 & 0 & I & o & o \\
\hline Total state tokens & 17 & 21 & 19 & 22 & 5 & 1 \\
\hline Total state types & 8 & 7 & 6 & 9 & 5 & 1 \\
\hline total inflected tokens & 8.4 & 10.3 & 6.9 & 8.0 & 3.1 & 0.6 \\
\hline Periphrastic past & & & & & & \\
\hline baver "existential be" & 0 & I & 0 & 0 & 0 & 0 \\
\hline estar, "be" & 0 & 0 & 0 & I & 0 & 0 \\
\hline ser "be" & 0 & 0 & 0 & 3 & 0 & 0 \\
\hline tenir "have" & 0 & 0 & 0 & I & 0 & 0 \\
\hline veure "see" & 0 & 3 & 5 & 8 & 3 & 5 \\
\hline pensar(-se) "think" & 0 & I & 0 & 1 & 0 & 0 \\
\hline imaginar(-se) "imagine" & 0 & I & 0 & o & 0 & I \\
\hline poder "can" & 0 & 0 & 0 & 0 & 0 & 1 \\
\hline Total state tokens & 0 & 6 & 5 & 14 & 3 & 7 \\
\hline $\begin{array}{l}\text { Total state types } \\
\text { Ratio state tokens / }\end{array}$ & 0 & 4 & I & 5 & I & 3 \\
\hline $\begin{array}{l}\text { total inflected tokens } \\
\text { nperfect }\end{array}$ & - & 5.1 & 2.5 & 2.9 & 2.0 & 0.4 \\
\hline baver "existential be" & 0 & 4 & 0 & 0 & 2 & 3 \\
\hline estar "be" & 0 & 2 & 0 & 0 & 0 & I \\
\hline
\end{tabular}




\begin{tabular}{lllllll} 
ser "be" & 0 & 1 & 3 & 2 & 2 & 4 \\
tenir "have" & 0 & I & 0 & I & 2 & 2 \\
voler "want" & 0 & 1 & 0 & 0 & 0 & 1 \\
veure "see" & 0 & 2 & 0 & 0 & 0 & 0 \\
poder "can" & 0 & 0 & I & 0 & 0 & 0 \\
faltar "be left," "remain" & 0 & 0 & I & 0 & 0 & 0 \\
Total state tokens & 0 & II & 5 & 3 & 6 & II \\
Total state types & 0 & 6 & 3 & 2 & 3 & 5 \\
Ratio state tokens I & & & & & & \\
total inflected tokens & - & 5.I & 1.2 & I.4 & 3.8 & 6.9 \\
\hline
\end{tabular}

Note. High-frequency statives are underlined.

TABLE 2. Inflection of state predicates in the Saint George retellings.

\begin{tabular}{|c|c|c|c|c|c|c|}
\hline & \multicolumn{2}{|c|}{ Daniel } & \multicolumn{2}{|c|}{ Barbara } & \multicolumn{2}{|c|}{ Robert } \\
\hline & Stage 1 & tage & Stage I & tage 2 & Stage I & tage 2 \\
\hline \multicolumn{7}{|l|}{ Present } \\
\hline baver "existential be" & 4 & 2 & I & 0 & 0 & 2 \\
\hline estar "be" & 5 & I & 4 & 0 & 0 & 0 \\
\hline ser "be" & 8 & 7 & 4 & 0 & I & 0 \\
\hline tenir "have" & 7 & I & 4 & 0 & 0 & 0 \\
\hline tenir que "have to" & 1 & 8 & 0 & 0 & 0 & 0 \\
\hline haver de "have to" & o & 0 & 4 & 1 & 0 & o \\
\hline voler "want" & 0 & 0 & 2 & 0 & 0 & 0 \\
\hline veure "see" & 0 & 0 & 2 & 0 & 0 & 0 \\
\hline quedar-se "keep" & 0 & o & I & 0 & 0 & 0 \\
\hline agradar "like" & a & 0 & 0 & 0 & 0 & I \\
\hline Total state tokens & 25 & 19 & 22 & I & I & 3 \\
\hline Total state types & 5 & 5 & 8 & I & I & 2 \\
\hline $\begin{array}{l}\text { Ratio state tokens / } \\
\text { total inflected tokens } \\
\text { Periphrastic past }\end{array}$ & II. 6 & 8.8 & I0.8 & 0.5 & 0.6 & 1.9 \\
\hline haver "existential be" & 0 & o & 0 & 0 & 0 & 0 \\
\hline estar "be" & 0 & 0 & 0 & 2 & 0 & a \\
\hline ser "be" & 0 & o & 0 & 0 & 0 & 0 \\
\hline tenir "have" & 0 & I & 0 & 0 & 0 & 0 \\
\hline tenir que "have to" & o & o & 0 & 0 & 0 & 0 \\
\hline veure "see" & 0 & 0 & 4 & 0 & 0 & 0 \\
\hline escoltar/sentir "hear" & 0 & 0 & I & 0 & 0 & 0 \\
\hline
\end{tabular}


quedar "remain"

Total state tokens

Total state types

$\begin{array}{llllll}0 & 0 & 0 & 1 & 0 & 0 \\ 0 & 1 & 5 & 3 & 0 & 0 \\ 0 & 1 & 2 & 2 & 0 & 0\end{array}$

Ratio state tokens /

$\begin{array}{lllllll}\text { total inflected tokens } & - & 0.5 & 2.5 & 1.5 & 0 & 0\end{array}$ Imperfect

\begin{tabular}{lcccccc} 
baver "have" & 0 & 6 & 0 & 2 & 7 & 6 \\
estar "be" & 0 & I & 0 & 0 & 0 & 1 \\
ser "be" & 0 & I & I & 2 & 5 & 2 \\
tenir "have" & 0 & 2 & 4 & 6 & I & 6 \\
tenir que "have to" & 0 & I & 0 & 0 & 0 & 0 \\
\hline baver que "have to" & 0 & 0 & 0 & 3 & 0 & 0 \\
poder "can" & 0 & 2 & 5 & 5 & 8 & 9 \\
pensar "think" & 0 & I & 0 & $\mathrm{I}$ & 0 & 0 \\
anar "lead" & 0 & 0 & $\mathrm{I}$ & 0 & 0 & 0 \\
témer "fear" & 0 & 0 & 1 & 0 & $\mathrm{I}$ & 0 \\
quedar "remain" & 0 & 0 & 1 & 3 & 0 & 0 \\
voler "want" & 0 & 0 & 0 & $\mathrm{I}$ & $\mathrm{I}$ & 0 \\
dgradar "like" & 0 & 0 & 0 & 0 & 0 & 0 \\
veure "see" & 0 & 0 & 0 & 3 & 0 & $\mathrm{I}$ \\
saber "know" & 0 & 0 & 0 & 1 & 2 & 0 \\
Total state tokens & 0 & $\mathrm{I} 4$ & $\mathrm{I} 3$ & 27 & 25 & 25 \\
Total state types & 0 & 7 & 6 & 10 & 7 & 6 \\
Ratio state tokens / & & & & & & \\
total inflected tokens & - & 6.5 & 6.4 & 13.2 & 15.7 & 15.7
\end{tabular}

Note. High-frequency statives are underlined.

TABLE 3. Inflection of state predicates in the conversations.

\begin{tabular}{lcccccc}
\hline & \multicolumn{2}{c}{ Daniel } & \multicolumn{2}{c}{ Barbara } & \multicolumn{2}{c}{ Robert } \\
\hline & Stage I & Stage 2 & Stage 1 & Stage 2 & Stage 1 Stage 2 \\
\hline Present & & & & & & \\
haver "existential be" & I6 & II & 0 & I & 0 & 0 \\
tenir "have" & 9 & 15 & 0 & 4 & 0 & 0 \\
ser "be" & 9 & 55 & 0 & 8 & 1 & 1 \\
poder "can" & 2 & 8 & 0 & 0 & 0 & 0 \\
recordar "remind" & 2 & 0 & 0 & 0 & 0 & 0 \\
estar "be" & 2 & 3 & 0 & 1 & 0 & 0 \\
voler "want" & I & 7 & 0 & 0 & 0 & 0 \\
agradar "like" & I & 3 & 0 & 0 & 0 & 0 \\
anar "go over" & I & 0 & 0 & 0 & 0 & 0
\end{tabular}


tenir que "have to" saber "know" veure "see" comprendre "understand" I dir-se "be called" conèixer "know" tardar "take" travessar "go accross" aparèixer/semblar "seem" o fer por "scare" pesar "weigh" necessitar "need" sentir-se "feel" durar "last" creure "think" pensar "tink" baixar "descend" importar "matter" Total state tokens Total state types Ratio state tokens / total inflected tokens Periphrastic past

$\begin{array}{lcccccc}\text { veure "see" } & \text { I } & 4 & 2 & 2 & 1 & 0 \\ \text { ser "be" } & 3 & \mathrm{I} & 0 & 0 & 0 & 3 \\ \text { aprendre "learn" } & 0 & 3 & 0 & 0 & 0 & 0 \\ \text { conèixer "know" } & 0 & 5 & 0 & 2 & 0 & 0 \\ \text { tenir "have" } & 0 & \mathrm{I} 2 & 0 & 3 & 0 & 0 \\ \text { creure "think" } & 0 & \mathrm{I} & 0 & 0 & 0 & 0 \\ \text { consistir "consist" } & 0 & \mathrm{I} & 0 & 0 & 0 & 0 \\ \text { sentir-se "feel" } & 0 & 4 & 0 & 0 & 0 & 2 \\ \text { ablidar "forget" } & 0 & \mathrm{I} & 0 & 0 & 0 & 0 \\ \text { tenir que "have to" } & 0 & \mathrm{I} & 0 & 0 & 0 & 0 \\ \text { fer "ago," "hurt," etc. } & 0 & 2 & 0 & 0 & 0 & 0 \\ \text { necessitar "need" } & 0 & \mathrm{I} & 0 & 0 & 0 & 0 \\ \text { haver "existential be" } & 0 & \mathrm{I} & 0 & 0 & 0 & 0 \\ \text { durar "last" } & 0 & \mathrm{I} & 0 & 0 & 0 & 0 \\ \text { notar-se "feel" } & 0 & 0 & 0 & \mathrm{I} & 0 & 0 \\ \text { entendre "understand" } & 0 & 0 & 0 & \mathrm{I} & 0 & 0 \\ \text { estar "be" } & 0 & 0 & 0 & \mathrm{I} & 0 & 0 \\ \text { Total state tokens } & 4 & 38 & 2 & 10 & \mathrm{I} & 5 \\ \text { Total state types } & 2 & \mathrm{I} 4 & \mathrm{I} & 6 & 1 & 2 \\ \text { Ratio state tokens / } & & & & & & \\ \text { total inflected tokens } & 0.4 & 4 . \mathrm{I} & 0.7 & 3.4 & 0.6 & 3.2\end{array}$


Imperfect

\begin{tabular}{|c|c|c|c|c|c|c|}
\hline haver "existential be" & 8 & 147 & $\mathrm{I}$ & 4 & 3 & 3 \\
\hline tenir "have" & 3 & 16 & o & 16 & I & 6 \\
\hline poder "can" & I & 3 & I & 3 & o & 3 \\
\hline ser "be" & 5 & 44 & 13 & 20 & 5 & 20 \\
\hline tenir que "have to" & 4 & 5 & 0 & I & 0 & 2 \\
\hline saber "know" & 2 & 6 & 1 & 7 & 0 & 0 \\
\hline creure "think" & I & I & 0 & 0 & 0 & 0 \\
\hline estar "be" & I & 28 & I & 2 & $\circ$ & 1 \\
\hline conèzxer "know" & 0 & I & I & 2 & o & 0 \\
\hline deure (aux.) "need to" & 0 & 2 & 0 & I & 0 & o \\
\hline sentir-se "feel" & 0 & I & 0 & 0 & 0 & 0 \\
\hline soler (aux.) "usually" & 0 & I & $\circ$ & 0 & 0 & 0 \\
\hline voler "want" & 0 & 2 & 4 & 2 & 1 & 2 \\
\hline permetre "allow" & 0 & I & 0 & o & 0 & 0 \\
\hline agradar "like" & o & o & 2 & I & 0 & I \\
\hline fascinar "fascinate" & 0 & 0 & I & I & 0 & 0 \\
\hline veure "see" & 0 & 0 & 2 & I & 0 & o \\
\hline existir "exist" & 0 & 0 & I & o & 0 & 0 \\
\hline trobar-se "feel" & 0 & 0 & o & I & o & 0 \\
\hline esperar "hope" & 0 & 0 & o & I & 0 & 0 \\
\hline fer "hurt," "be hot" & o & o & 0 & 3 & 0 & 0 \\
\hline pensar "think" & 0 & o & o & I & 0 & 0 \\
\hline imaginar "imagine" & 0 & 0 & o & 2 & 0 & o \\
\hline escoltar "hear" & 0 & 0 & 0 & I & 0 & 0 \\
\hline girar "turn" & 0 & 0 & 0 & I & o & 0 \\
\hline haver de "have to" & 0 & 0 & 0 & 4 & 0 & 0 \\
\hline aprendre "learn" & 0 & 0 & 0 & 4 & 0 & 0 \\
\hline notar-se "feel" & 0 & o & 0 & I & 0 & 0 \\
\hline dir-se "be called" & 0 & 0 & o & I & o & 0 \\
\hline semblar "seem" & o & 0 & o & I & 0 & 0 \\
\hline caure "be" & 0 & 0 & 0 & 0 & 0 & I \\
\hline Total state tokens & 25 & 258 & 28 & 82 & Io & 39 \\
\hline Total state types & 8 & 14 & II & 25 & 4 & 9 \\
\hline Ratio state tokens / & & & & & & \\
\hline total inflected tokens & 2.7 & 27.7 & 9.5 & 27.7 & 6.3 & 24.7 \\
\hline
\end{tabular}

Note. Some predicates were coded as states even though the verb used by the participant would not be considered a state in the target language. For instance, girar "to turn" referred to the way a path turned; caure "to fall" referred to the date for a birthday. Highfrequency statives are underlined. 